\title{
The Institution of the Users Interested in the Financial Control Information
}

\section{Andrey Gennadievich Lukin}

\author{
Samarskij Gosudarstvennyj Universitet, Samara, Russian Federation
}

\section{Doi:10.5901/mjss.2015.v6n4s4p432}

\begin{abstract}
The article analyzes modern theoretical approaches to organization and verification of financial control in the Russian Federation and abroad. As a result of this analysis, it is substantiated that the further development of the financial control theory, which is based on the improvement of inspectors and auditors' work, has no prospect. This area has no development opportunities. The research results and practical experience in financial verification by economic entities of different ownership forms showed that the main reasons for the increased number of claims to the results of the inspectors and audits' work are rooted not in the negligent inspections. It is because the customers and organizers of financial control are not always able to formulate the purposes of the control correctly or do not know how to use the information provided by the inspectors. Consequently, it is proposed to study the owner's or top manager's behavior, as the basis for the entire system of the financial control, both at the micro- and macroeconomic level. It gives the concept of the interested user, and identifies the attributes of the new socioeconomic institution formation-a user interested in the financial control information.
\end{abstract}

Keywords: finance, the financial control, state financial control, interested user.

\section{Introduce the Problem}

Financial control essentially is a unique phenomenon. Financial relationships, anyway, exist almost in every sphere of modern life. They significantly influence both the course of socioeconomic processes and the achievement of socially and economically significant results in the course of various problems solution.

Therefore, it is surprising that, despite the sufficiently long history of economic and financial relations, today there is no common understanding of financial control as an economic phenomenon. There are several isolate theories that likely do not complement each other but compete with each other, frequently denying each other entirely. This hinders the development of the theoretical positions of financial control as a whole.

\subsection{Importance of the Problem}

Countries with a market economy accepted audit as the theoretical basis of financial control. Audit is a theory for financial inspectors who operate on the commercial basis, an external control variety, i.e. control independent from the owner. In addition, it is the main core, on which the theory of audit is based. This implies that the owner who has ordered the audit services knows what he will do with the information provided by the auditor. In contrast to audit, the theory of national economic control was developed in the USSR. The methodology was based on the public control concept, according to which the state financial control was carried out by public control authorities, as the representatives of the nominal holder of the state property-the people. Again, the theory was totally focused on the activities of these authorities, i.e. on the ways and methods of implementation of the control activities. Herewith, it was assumed that the government understood how it should use the information received by the public control bodies.

However, due to some of its provisions, this theory could not function outside the administrative-command system for two main reasons. In the first place, the theory of public control reduced the entire financial control to the state and public financial control, leaving no room for other types of financial control, especially in the field of private property. In the second place, public control was carried by inspectors selected from the personnel, not by professionals, which also does not make it trustworthy in the market economy conditions.

Unfortunately, the theory of public control was rejected both abroad and in the Russian Federation completely, as it was found inconsistent with the market reality, especially with regard to the mentioned fundamental aspects. However, the methodology of these theories had much in common. With different approaches, they might have successfully complemented each other.

Therefore, in the present conditions, the theory of audit remains the only theory of financial control. Modern 
science tries to apply the audit theory provisions not only to the commercial audit, but also to the organization of internal and state financial control.

However, modern research shows that audit does not provide high-quality results of the financial control. For example, according to certain sources, at the end of the last century, nearly 4,000 lawsuits a year to the total amount of 30 billion dollars were brought against auditors in the USA. In 1960-1985, more than 60\% of such claims were satisfied wholly or in part. In 1988, more than 1 billion dollars were paid in the USA to lawsuits brought against auditors (accountants) (Nozhkina, 2007)

\subsection{Describe Relevant Scholarship}

Nowadays, the financial control research is divided into several areas virtually isolated from each other.

The base for the financial control research is the study of the organization and implementation of the audit work. Scientists, such as R. Adams, A. Arens, J. Loebbecke, R. Dodge, D. Irwin, J. Robertson and others, studied the methodological problems of financial control and audit. In the Russian Federation, the publications by M.A. Azarskaya, V.G. Belolipetsky, V.V. Burtseva, T.E. Gvarliani, E.Yu. Gracheva, O.A. Mironova, V.M. Rodionova and others approached the issues of the financial control methodology.

The state financial control is a separate issue. Abroad, it is associated mostly with the problems of public administration, parliamentarism, and federalism. Anyway, the organization and implementation of state financial control are discussed in works by S. Braden, J. Phillips, R.A. and P.B. Musgrave, D. Rodrik, J. Sandkuist, P. Samuelson, H. Havens and others.

In Russia, state financial control is considered as a separate phenomenon. It was studied by V.V. Burtsev, E.Yu. Gracheva, T.G. Nesterenko, V.G. Panskov, S.O. Pogosyan, M.V. Romanovsky, S.V. Stepashin, L.A. Muravyova, P.V. Chernomord, S.O. Shokhin, etc.

\subsection{State Hypotheses and their Correspondence to Research Design}

Unfortunately, scientific findings and results for each of these areas are not popular and have little impact on the science development in other areas of research, even though the same scientists were engaged in their study.

Therefore, there is no systematic approach in the organization and implementation of financial control, as well as in scientific researches, which approach would allow considering the issue in general conceptually. Scientists and experts try to solve some local problems without realizing that it is necessary to change the very ideology of financial control both at the micro- and macro-level.

Attempts to apply the theory of audit to the internal financial control, as well as to the organization of the state financial control, without changing its principles, look quite clumsy. Furthermore, there is no further capacity to improve the inspectors and auditors' work. Nowadays, the improvement of their methodology is based on the development of information technology, which enables remote monitoring of the financial activities of companies.

That is why the main task was to identify the factor, which (along with the inspectors and auditors' activity) has a significant influence on the results and effectiveness of financial control.

\section{Method}

\subsection{Method of historical analysis}

Foreign science, besides the theory of audit, also has a vast experience and long traditions in the financial control implementation in the circumstances of the market economy. Such a combination allows finding the right solutions virtually by intuition. Most clearly, this statement is confirmed by the example of the state financial control organization. The history of state financial control in various countries is rather long (for example, Germany introduced it in 1714 (the establishment of the "General Audit Chamber") (Kupriyanov et al., 2003); the UK-in 1314 (the introduction of the title of the Comptroller of Treasury of His Majesty the King of England, Edward II) (Petrakova, 2008)). However, many countries have mainly started to use the modern models not so long ago. The United States were first to start using the current model in 1921 (Budget and Accounting Act). It was a result of the long-term budget reform (the end of the XIX century) (Philip, 2014). Germany established the modern system of state financial control in 1950 (German Law of 07.11.1985). The UK did it in 1983 (National Audit Act, 1983). The generalized recommendations of the global financial community of state financial control organization were introduced in 1977 as a result of the INTOSAI Conference in Lima (Peru) (The 
Lima Declaration of Guidelines on Auditing Precepts, 1977).

This shows that the created systems were the result of the long analysis of the experience of application of different models of state financial control organization in different countries. The recommendations of the Lima Declaration are the quintessence of the experience. Therefore, the Russian researchers believe that the development of the theory and practice of state financial control abroad is determined by two factors. The first is the experience of the national legislative development. The second is the principles of the Lima Declaration of the guidelines on auditing precepts adopted during INTOSAI in 1977 (hereinafter - the Lima Declaration) (Eurasian Law Journal, 2012).

According to the studies of foreign scientists, the development of state financial control in developed countries has had a significant impact on the development and consolidation of the state power. For example, James Sundquist wrote that the modern presidential power finally formed in the United States on June 10,1921, when President Harding signed General Accounting Law (Sundquist, 1981).

Herewith, officials implementing the state financial control are usually also called auditors, and therefore their work is regulated by the postulates and principles of the theory of audit. Although, they are not the commercial auditors.

The Russian Federation chose its own way of development of the financial control theory. Firstly, there was a complete rejection of the theory of national economic control including all its positive and negative properties, which meant the rejection of all previous years of experience in organizing and implementing financial control. Secondly, it selectively accepted the theory of audit at the micro level, as well as the recommendations of the Lima Declaration at the macroeconomic level. It was the beginning of process of transforming the theoretical provisions to fit the Russian reality.

\subsection{Comparison method}

The only theory that could be applied in the present conditions in the Russian Federation was the theory of audit, which is being promoted nowadays. But even here, we can see the "Russian approach" to the development of a new theory.

The organization of internal audit particularly clearly demonstrated the features of the Russian approach. If you follow the development of percepts of internal audit from recognized authorities of the theory of audit to the modern Russian studies, you will have the following picture.

English scientist R. Adams defined internal audit as "an element of the internal control system created by the administration to check, assess, and report on accounting records and other components of the economic activity control" (Adams, 2003). The clause that internal audit is only an element of the internal control system is noteworthy. R. Dodge shared the same view. He believed that "internal audit is a component of internal control, which is carried out by decision of the company management for the purposes of monitoring and analysis of the economic activity" (Dodge, 2002). Herewith, they point to the limited application scope of internal audit.

It is assumed that internal audit is just one of the components of the internal control system along with other instruments and techniques of internal control. In particular, in the USA, it is recommended to use the technique described in the document published by the Committee of Sponsoring Organizations of the Treadway Commission (COSO), entitled "Conceptual foundations of internal control" (Committee of Sponsoring Organizations of the Treadway Commission (COSO), 1992). The similar technique PIfC is recommended in the EU (The Compendium of the public internal control systems in the EU Member States, 2012).

Another line is the development of management standards. The International Organization for Standardization (IOS) has developed and successfully distributes around the world the guidelines of the quality management standard ISO 2000: 9000. These guidelines include the process approach and appropriate methods of self-control and mutual control, including financial (ISO 9000:2000 Quality management systems, 2002).

However, Russian scientists considered internal audit differently. For example, R.A. Alborov believes that "internal audit is in fact the in-house control" (Alborov, 1998). According to V.D. Andreev, internal audit should be "... widely understood as a function of management, a form of internal control ..." (Andreev, 2008). Professor V.V. Burtsev believes that the "internal audit is the regulated by internal documents organization's activity on controlling the management units and various aspects of the organization operation, performed by the representatives of the special supervisory body as part of the assistance to the management bodies of the organization..." (Burtsev, 2003). In other words internal audit is not considered as one of the elements of the system with a limited set of functions, but as the basis and the only methodology of implementing the entire internal control in the organization.

At the same time, other methods of internal control are applied in the Russian Federation only if necessary, for example, in case of establishment of joint ventures with European and American partners. 


\subsection{Method of statistical monitoring}

It should be mentioned that the foreign practice also faces certain problems. As the scientists studying audit argue based on their research, despite the theoretical symmetry and standardization, audit is not the panacea of financial irregularities and abuses. Adams wrote that none of the major accounting company had managed to avoid prosecution for negligence under common law, the initiators of which were both clients and third parties (Adams, 2003).

Different authors classify the start of mass prosecutions against auditors in the West to the 1960s, i.e. a little later than the audit became widely spread. This fact is very interesting for a variety of participants of the Russian market of audit services. In the 1970-80s, the number of such processes increased significantly. For example, in the 1960-1972 in the United States there were 181 cases, and in 1973-1985-291 cases (Nozhkina, 2007). According to scientists, the series of corporate scandals in the USA, which involved the largest audit companies, caused the financial crisis of the beginning of the XXI century (NEWSru.com, 2002).

\section{Results}

Russian and foreign studies consider various options for improving audit. They are aimed at correcting its deficiencies. It is proposed to increase the transparency of the audit firms' activity, improve the methods for determining the audit risks, etc. For example, in 2007 in the United States, the standards of state audit (GAGAS) were edited to address the transparency and accountability issues (Starovoitova, 2011). However, such actions, unfortunately, do not provide the expected results.

Therefore, there is a real necessity today to review the basic approaches to consideration of the theory of financial control. It is obvious that focusing only on the methodology of implementation of the control activities of specialized financial control bodies or auditors has no further prospects. The practice shows that no matter how financial control instruments are improved, a certain important element is missing, which would be able to enhance the advantages and reduce the disadvantages of theoretical views, on the one hand, and give a new impetus to the development of the financial control theory, on the other hand.

We believe that this element is the interest of the owner (mercenary manager) in the information, with which financial control provides him. As already noted in this study, current theories of financial control and audit assume that during the organization of financial control or when concluding an agreement for the auditing services, the owner or mercenary manager clearly understand why they do it. In the theory of audit, the client who orders audit services is called an "interested user". We suggest to apply this name to all who are directly interested in obtaining comprehensive, accurate, and timely information about the real state of affairs in the audited organization (business unit).

However, the author's research and personal experience show that those who should be the interested users are not always interested. Particularly, it concerns to the mercenary managers, whom the owner or the state as the owner, have delegated the authority to manage their property and organize or use their financial resources. However, it also concerns individual owners as well, who for some reasons want to hide or skew the results of their financial activity from the society or government.

It was determined that information received in the course of financial control, not only supplies the interested users with information on the compliance with the rules, which they have established, and achievement of the planned results, but also makes them to follow the established rules themselves within the framework of their professional activity. In fact, any interested user's deviation from the established rules is reflected in the financial performance of the company as a whole and the financial control signals about it immediately.

Another important aspect of the necessity to consider the theoretical positions of the interested user's behavior is that under the current theories, a large number of different methods of control were developed. Today, it is quite difficult for interested users to understand all the subtleties and nuances of using a certain technique more effectively. But it is the interested user, not a visiting auditor or internal inspector, who should decide, which technique is more appropriate. In fact, only an interested user can formulate the purpose of financial control at this stage of the company's development, associate the parameters to control with the forms and methods of this control, etc. Science must become the main assistant of the interested user in addressing these issues. For example, we proposed formulation of postulates and principles of state financial control from the position of an interested user-the government (Lukin, 2013). In addition, we proposed different models of organization of the financial control system, according to the management structure of the company (Lukin, 2013), and others. 


\section{Discussion}

Based on the above, we concluded that it is important to consider the issues of organization and financial control from the position of users interested in the financial control information for understanding the actions of the owner (mercenary manager) implementing his intention to organize an effective and efficient system of control over the formation and use of financial resources.

It is possible to formulate the concept of the user interested in the financial control information, represented by the owner of the organization's assets (a mercenary manager, to whom the owner has delegated the authority to manage these assets) who implements a set of measures based on personal, financial or official interest to prevent breaches of the legislation requirements formulated within the framework of the state regulation of financial activities, the rules of financial activity of the company, set by himself, and to achieve the planned financial results, as well as improve the financial management of the company.

Interested users provide monitoring independently. If necessary, the information required for the control can be supplied by:

- corporate governance within the established management structure;

- specially created bodies (units) of financial control;

- external financial control bodies employed for these purposes (commercial audit) or established by the government (state financial control).

Interested users organize financial control in stages. At first, they define the rules of financial activity established by the state within the state control framework, which the established (leaded) business entity must abide by. Then, they define the financial strategy of the company and (if necessary) formulate their own rules of financial activity in addition to the state ones, as well as targets, parameters, and financial results to achieve. The next step is to define the control system parameters over the observance of these rules, and composition of the financial control information and the procedure for its collection. The last step is to develop the measures of response to the financial control information. These include both enforcement of those who do not abide by the rules and a flexible system of changing the approved rules, parameters, and results if they do not contribute to achieving the goals.

An interested user cannot entrust the organization of financial control to anyone else. The user must actively involve the management of the organization for the control purposes, using it as a monitoring tool. But he cannot delegate his power of financial control to someone else. Otherwise, he will have no reliable, comprehensive and timely information, which in this form is needed only by him, and simply will not able to manage the financial situation.

The suggested methodology of financial control is based on the interests of users interested in the financial control information. It allows solving many problems, which cannot be solved from the position of current approaches. For example, to understand why assigning additional extensive powers to the control authorities, such as access to documents and even enforcement measures, further promotion of openness and transparency of financial control do not give the expected effect. Even vice versa, cause the situation, when these authorities begin to identify new types of violations, which significantly affects the economic performance.

Nowadays in terms of current approaches, there is no way to solve this problem. If inspectors and auditors have such power, it will lead to the same results. However, from the position of an interested user, that problem can be solved by returning the owners (managers) to the financial control system. They are the ones who create the rules. Thus, they will start to respond to the financial control information obtained by the auditors, by analyzing, inter alia, the effectiveness of the rules established by themselves, because the audit institutions, even assigned with very extensive powers, are unable to correct the situation. This can be done only by an interested user.

From the point of view of an interested user, we can completely describe the essence of financial control and divide the concepts of financial control and monitoring activity. Such division helps understand that the control activity, i.e. the creation of barriers for financial violations and acquisition of information on abidance by the control objects by the established rules and standards, as well as achievement of the planned results, carried out by inspectors and auditors is only a part of financial control. Another important part is the process of developing the rules and procedures to respond to the information obtained during the control activities, including, if necessary, correction of the rules. This is the prerogative of an interested user. From this perspective, we have managed to offer a solution of certain problems relating to the organization and implementation of the state financial control in the Russian Federation (Lukin, 2014).

\section{Conclusion}

Thus, considering an interested user as the subject of financial control, we need to note that he bears all the responsibility 
for its organization and implementation, acting as the regulator of all processes taking place within the financial control. He determines both the successful use of financial control tools, which results in effective solution of problems and subsequent achievement of the organization's goals, and the failures in the control activity, which usually lead to the opposite result.

In addition, owners, which also include both the state and mercenary management (including state managers), make up a large social group. The successful application of scientific achievements in the area of financial control actually depends on them. There is every indication of institutionalization, i.e. formation of an informal economic social institution - the institution of financial control information users in the sense, as the modern science understands it (Stanford Encyclopaedia of Philosophy, 2011).

We consider that nowadays, state regulation of the institution of interested users is necessary at both the macro and microeconomic level systems right up it becomes a formal institution. Such regulation will bring the "state - owner," "owner - mercenary manager," and "owner - worker" relations to a new level, helping owners solve many financial problems that they have to deal alone nowadays.

\section{References}

Adams, R. (2003). Basics of audit (pp.250, Sokolova, Ya.V., Ed., Trans.) Moscow: Audit, UNITY. [In Russian]

Alborov, R.A. (1998). Audit in industry companies, commerce and agribusiness (pp.463) Moscow: Business and Service. [In Russian] Andreev, V.D. (2008). Internal audit (pp.464). Moscow: Finance and Statistics. [In Russian]

Budget and Accounting Act. Retrieved from: http://www.gao.gov/about/history/articles/working-for-good-government/01 introduction.html Burtsev, V.V. (2003) Internal audit of the company: organization and administration. Finansovy Menedzhment, 4, 8-15. [In Russian]

Dodge, R. (2002). Standards and norms of audit quick guide (pp. 220, Trans.). Moscow: Sirin. [In Russian]

Germany Law "On the Federal Court of Auditors" dated 11.07.1985 (2003). Bulletin of the Accounts Chamber of the Russian Federation, 4(64), 244-249. Retrieved 31.07.2014 from: http://audit.gov.ru/upload/uf/d06/d0661406b4c9bcf471abafe7f5d164 c0.pdf

Internal Control - Integrated Framework (1992). Committee of Sponsoring Organizations of the Treadway Commission (COSO). New York: AICPA

ISO 9000:2000 Quality management systems. Fundamentals and vocabulary. Retrieved from: http://www.iso.org/iso/catalogue_detail? csnumber $=29280$

Lukin, A.G. (2013) Postulates and Principles of State Financial Control and Their Application in the Russian Federation. Middle-East Journal of Scientific Research, Vol.17, 5, 668-672.

Lukin, A.G. (2013) Organization of financial control system in the application of various management structures. Finansy $i$ Kredit, 22(550), 48-61. [In Russian]

Lukin, A.G. (2014) State budget control in the Russian Federation: the current state and development prospects (pp. 186). Moscow: INO Publishing House "Scientific survey." [In Russian]

National Audit Act (1983). Retrieved from: http://www.legislation.gov.uk/ukpga/1983/44/contents

New corporate scandal has shaken America (June 26, 2002). Retrieved 25.08.2014 from http://www.newsru.com/finance/26Jun 2002/worldcom.html [In Russian]

Nozhkina, T.V. (2007). International audit (pp. 127). Petropavlovsk-Kamchatsky: KamchatGTU. [In Russian]

Petrakov, S.G. The history of the state financial control formation in the UK. Library of accounting and tax documents. Retrieved 10.01.2015 from: http://www.naloglib.net/008/puti-stanovleniya [In Russian]

Philip, D. (2014). Informed Budgeting in the United States: evolutionary approach. Gosudarstvenny Finansovy Kontrol, Journal-annex to the newspaper Gosudarstvenny Finansovy Kontrol, 5, 45-53. [In Russian]

Report from scientific research work. Analysis of organizational and legal models of state external financial control functioning in the government of foreign countries (in terms of some foreign countries) in section Patterns of functioning and reporting standards in the government of developed countries - Retrieved 10.01.2015 from: http://rudocs.exdat.com/docs/index-565406.html [In Russian]

Social Institutions. Stanford Encyclopaedia of Philosophy. Retrieved from: http://plato.stanford.edu/entries/social-institutions/

Starovoitova, K.V. (2011) Risks in the standards system of the state audit in the USA. Audit i Finansovy Analiz, 3, 19-24. [In Russian]

Sundquist, J. (1981). The Decline and Resurgence of Congress (pp. 500). Washington, DC: Brookings Institution Press.

System and principles of financial control in the European countries (2012). Eurasian Law Journal, 3(46). Retrieved from: http://www.eurasialegal.info/index.php?option=com_content\&view=article\&id=1107:2012-04-09-03-20-27\&catid=1: eurasianinte gration\&ltemid=1 [In Russian]

The Compendium of the public internal control systems in the EU Member States (2012) . Retrieved from: http://www.pifc.eul

The Lima Declaration of Guidelines on Auditing Precepts. Retrieved from: http://www.intosai.org/documents /intosai/general/ declarations-of-lima-and-mexico/lima-declaration.html 